\title{
DOCUMENTO
}

\section{JOHN LOCKE: ALGUNS PROBLEMAS REFERENTES À EDUCAÇÃO DO POBRE}

DOI: http://dx.doi.org/10.1590/2236-3459/72220

\author{
Elomar Antonio Callegaro Tambara \\ Universidade Federal de Pelotas, Brasil.
}

\author{
Eduardo Arriada
}

Universidade Federal de Pelotas, Brasil.

\section{$\cos 80$}

ndiscutivelmente a contribuição de John Locke pode ser considerada um dos principais pilares na estruturação do pensamento moderno particularmente da ideologia liberal e com importante contribuição na área de História da Educação. Personalidade fortemente inserida na sociedade inglesa de seu tempo, colaborou decisivamente para configurar uma nova sociedade e um novo cidadão.

$\mathrm{Na}$ Inglaterra, com a morte de Elizabeth I, em 1603, acentuaram-se os conflitos entre os paradigmas políticos, que de um lado privilegiavam o processo de consolidação dos interesses da burguesia em formação e de outro lado os interesses da monarquia absolutista. Evidentemente era uma negociação política que no governo de Elizabeth I e mesmo no período de Henrique VII (1491-1547) pautava os movimentos sociais e políticos na Inglaterra.

Entretanto, é importante ter presente que a derrota do absolutismo político está marcada pela conhecida "Revolução Gloriosa" (1688-89), pela qual fica plasmado que o poder decorria e fundamentava-se no parlamento.

Um aspecto importante neste processo é compreender que a Inglaterra já se configurava como um Estado Nacional, o que Ihe proporcionou vantagens no período de 
consolidação do sistema capitalista de produção.

Houve uma aceleração no processo de expropriação das terras dos camponeses, que passaram a ser utilizadas para os rebanhos de ovelhas destinadas a produzir lã para a industria têxtil.

Embora este seja um elemento importante na "gênese do pobre". Esta é uma questão que precede este momento histórico. Exemplo disto é a "Poor Law Act", de 1388, que tinha como objetivo controlar os movimentos dos pobres de modo a restringir que os trabalhadores pudessem sair de sua paróquia civil a procura de novos postos de trabalho. Muitos ordenamentos jurídicos foram criados para equacionar esta questão e que tem um marco emblemático na Poor Law de 1601.

A passagem da formação sócio econômica feudal para a capitalista, como é sabido, provocou a emergência de uma multidão de despossuídos condenados a vaguear pelo país vivendo da mendicância e, eventualmente, de furtos e roubos. A reação do Estado foi a promulgação de uma série de leis, normas, atos, com o intuito de enquadrar estes indivíduos aos interesses da formação social capitalista em gestação. Este aparato jurídico determinava que os mesmos fossem açoitados, mutilados (corte da orelha) e mesmo executados ao serem apanhados cometendo estes delitos.

$\mathrm{Na}$ tentativa de equacionar esta questão social, a par das medidas legais, houve um movimento que reuniu diversas entidades, congregações religiosas, organizações civis, estruturas estatais, que se mobilizaram e encontraram como solução a instalação das "Workhouses". Estas instituições tinham condições de fornecer, ao parque industrial em formação, mão de obra barata, com uma relativa formação técnica e, principalmente, adestramento disciplinar.

Com o intuito de adequar a mão de obra às novas necessidades do sistema fabril e equacionar os problemas sociais ocasionados pela "vagabundagem", várias alternativas foram criadas na Inglaterra, nos séculos $\mathrm{XV}$ e XV, como asilos, escolas paroquiais, hospícios, mas sem dúvida este tipo de organização benemerente de modo geral vinculado à Igreja teve um salto "qualitativo" com a Primeira Lei dos Pobres .implantada pela rainha Elizabeth I em 1601. que institucionalizou as workhouses e consolidou-se com melhor estrutura jurídico-política com a Segunda Lei dos Pobres implantada pelo rei George III em 1834.

Estas instituições não apresentavam características uniformes e dependiam fundamentalmente dos recursos econômicos das diversas paróquias civis e apresentavam grandes disparidades. Eram estabelecimentos que abrigavam camadas sociais que estavam à margem do processo econômico (criminosos, ociosos, crianças, enfermos, homens e mulheres) oferecendo abrigo, vestuário e alimentação em troca de trabalho e que, em muitas delas, abrigavam também um sistema escolar. Caracterizando um típico empreendimento de caráter assistencialista e de formação profissional.

A função principal destas "escolas" era retirar de circulação elementos considerados casos desviantes pelo sistema e torná-los cidadãos com os hábitos concernentes a nova ordem capitalista: ordeiro e trabalhador.

Até que ponto, estes estabelecimentos tiveram sucesso é muito discutível e, sem dúvida, variou muitos entre eles. A análise feita por Marx revela que muitos de seus professores eram absolutamente analfabetos, e, de modo geral, poucos se diferenciavam dos aprendizes. Revelando que as workhouses funcionavam muito mais como um campo 
de confinamento do que de aprendizagem profissional.

Um exemplo, dentre vários descritos por Marx:

\begin{abstract}
Segunda escola, a sala de aula tinha 15 pés de comprimento por10 pés de largura e continha 75 crianças que grunhiam algo ininteligível. Mas não é apenas nesses lugares miseráveis que as crianças recebem atestados de freqüência escolar e nenhum ensino; existem muitas escolas com professores competentes, mas seus esforços se perdem diante do perturbador amontoado de meninos de todas as idades, a partir de 3 anos. Sua subsistência depende totalmente do número dos pence recebidos do maior número possível de crianças que consegue empilhar num quarto. Além disso, o mobiliário escolar é pobre, há falta de livros e de material de ensino e uma atmosfera viciada e fétida exerce efeito deprimente sobre as infelizes crianças. Estive em muitas dessas escolas e nelas vi filas inteiras de crianças que não faziam absolutamente nada, e a isto se dá o atestado de freqüência escolar; e esses meninos figuram na categoria de instruídos, de nossas estatísticas oficiais (MARX, 1985, p. 457).
\end{abstract}

Locke não possuía apenas uma vida voltada à produção intelectual-filosófica, ao contrário, exerceu diversos cargos públicos. Devido à gangorra política que caracterizava a Inglaterra no século XVII fizeram-no passar dois anos em Montpellier (1675-77) e mais tarde residir na Holanda. Só regressou à Inglaterra depois da revolução de 1688. Com a ascensão de Guilherme de Orange ocupou o posto de Comissário Real do Comércio e das Colônias, publicando importantes obras: Carta sobre a Tolerância; os Dois Tratados Sobre o Governo Civil e, em março de 1690, a sua obra mais significativa: Ensaio sobre o Entendimento Humano.

$\mathrm{Na}$ área da História da Educação é de peculiar importância sua obra "Alguns Pensamentos Referentes à Educação", publicada em 1693. Apesar do reconhecido valor deste trabalho, que representa uma exemplar aplicação da teoria do conhecimento de viés empirista aos problemas do ensino, a obra tardou em ter sua versão em português.

Uma idéia basilar que Locke advoga neste trabalho é que o homem não possui ideias inatas e o conhecimento está vinculado à experiência sensível e à reflexão, de forma análoga, o poder não é inato ou de origem divina, concepção que o leva a defender a soberania do povo.

Não restam dúvidas que a historiografia da educação dá um destaque especial à contribuição de John Locke na origem do processo de conformação de um sistema educacional destinado à formação do gentil homem, do gentleman, do cavalheiro, e por fim, e talvez decorrência, da formação do homem novo - o burguês.

Tal ênfase tem obscurecido e quiçá obliterado as contribuições deste pensador em relação às classes populares, que não é muito encontrada nem nos manuais de história da educação, tampouco nas análises que contemplam o estudo da história das idéias pedagógicas.

Com o intuito de contribuir para preencher esta lacuna, apresentamos nesta seção da Revista o trabalho de Locke intitulado "Proposta de uma representação contendo um esquema de métodos para a inserção empregatícia dos pobres", publicado em 1671, onde o mesmo faz uma explanação sobre medidas adequadas para equacionar os problemas vivenciados pela sociedade inglesa em relação à população pobre e, dentre estas sugestões, há muitas proposições que contemplam a educação. De modo que a apreensão destas propostas contribui em muito para delinear o modo peculiar com que 
Locke contrastava a formação educacional das diversas classes sociais que compunham a sociedade inglesa.

Como é de todos sabido, o liberalismo comporta formas muito diferentes de conceber a sociedade, desde a defesa do livre mercado, com efetiva hostilidade ao Estado, até manifestações como as lutas pelo direito ao aborto, ao casamento homossexual, ao feminismo, e, no caso específico, frequentemente aporta na defesa da universalização da educação.

De qualquer modo, o pensamento de Locke, apesar de ser considerado como um dos filósofos fundadores do liberalismo, precisa ser apreendido com certo cuidado. Não se deve olvidar que é um filósofo do século XVII. Seu empirismo tem muito de uma construção teórico-epistemológica de seu tempo. O que é muito diferente das construções gnosiológicas do século XIX, por exemplo.

Esta atenção é importante, particularmente no documento que publicamos, que ainda "respira a Primeira Lei dos Pobres". Em diversos pontos advoga a clara intervenção do Estado na solução do problema dos pobres e, de certa forma, responde pelo pragmatismo liberal que propugna reduzir ao mínimo a ingerência do Estado naquilo que pode ser dispensado ou suprido pela iniciativa privada e incrementar ao máximo onde circunstancialmente esta tem que ser exercida.

Nota-se que Locke identifica o problema nas características pessoais da população pobre, pois, segundo ele, a dificuldade não residir "nem na escassez de provisões nem na falta de emprego para os pobres". Neste sentido, ele localiza o problema do crescimento do número de pobres no relaxamento da disciplina e na corrupção dos hábitos, assim como no vício e na ociosidade. Em consequência, a primeira medida para equacionar este problema "deve ser a restrição de sua libertinagem".

O embarque em navios (onde devem servir três anos sob rígida disciplina), particularmente nos condados marítimos, é a alternativa proposta, pois as outras propostas não têm dado a resposta esperada.

Quanto às crianças (abaixo de quatorze anos de idade) que forem encontradas mendigando devem ser enviadas para a próxima working-schools - "onde [o infante] deve ser exaustivamente chicoteado e mantido no trabalho até o anoitecer, para que possa ser mandado embora com tempo suficiente para que consiga chegar ao seu lugar de moradia ainda naquela noite". Se morarem a mais de cinco milhas, "que sejam enviadas para a próxima casa de correção, para lá permanecerem trabalhando por seis semanas".

Segundo Locke, é preciso ter atenção especial com os filhos das pessoas trabalhadoras e que "normalmente são mantidos na ociosidade", cuja solução seria serem enviados para as working-schools, as quais seriam estabelecidas em todas as paróquias. Nestas, a frequência seria obrigatória e com seu trabalho, as famílias poderiam pagar, pelo menos em parte, seu custeio. A frequência das crianças nestas escolas teria também um claro viés de formação moral e religiosa. Segundo Locke,

Uma outra vantagem também em trazer crianças pobres para uma workingschools é que desta forma elas podem ser obrigadas a ir constantemente à igreja todo domingo juntamente dos seus mestres escolares ou damas, onde elas podem ser trazidas à algum sentido religioso; ao passo que atualmente, no seu 
ocioso e livre modo de criação elas são completas estranhas tanto à religião e à moralidade como à diligência.

Vê-se que as concepções de Locke estão bem integradas às transformações econômicas que residem na gênese do sistema capitalista. Neste sentido, propõe "que estas escolas sejam geralmente para tecelagem e tricô, ou outra parte da produção de lã". Tal perspectiva visava inclusive, além da inserção no sistema produtivo, a possibilidade de "pagar os próprios custos, com um superávit".

Locke propõe esta solução (working-schools) também para as pessoas adultas "que podem vir às referidas escolas profissionalizantes para aprender".

Estas e muitas outras sugestões que estão neste texto poderão, sem dúvida, trazer uma forte contribuição para os investigadores da área da história da educação e outras áreas afins.

\section{Referências}

LOCKE, John. Alguns problemas referentes à educação do pobre. 1693.

MARX, Karl. O capital. São Paulo: Abril, tomo 2, 1984.

ELOMAR ANTÔNIO CALLEGARO TAMBARA é professor titular da Universidade Federal de Pelotas e integrante do Centro de Investigações em História da Educação - Ceihe.

Endereço: Caixa postal 628 - 96010-971 - Pelotas/RS - Brasil.

E-mail: tambara@ufpel.edu.br

EDUARDO ARRIADA é professor adjunto de História da Educação na Universidade Federal de Pelotas e integrante do Centro de Investigações em História da Educação - Ceihe.

Endereço: Rua D. Pedro II, 414 - 96010- 300 - Pelotas/RS - Brasil.

E-mail: earriada@hotmail.com

Recebido em 10 de fevereiro de 2017.

Aceito em 22 de março de 2017. 


\section{JOHN LOCKE: ALGUNS PROBLEMAS REFERENTES À EDUCAÇÃO DO POBRE}

\section{Proposta de uma representação contendo um esquema de métodos para a inserção empregatícia dos pobres. Proposto pelo Senhor Locke, em 26 de outubro de 1697.}

Para vossa excelência senhores da justiça

Com a permissão da vossa excelência

Vossa Majestade estando satisfeita, pela sua comissão, a requerer que nós particularmente consideremos alguns métodos apropriados para definir o trabalho e inserção empregatícia dos pobres neste reino, e fazê-los úteis ao público, e assim aliviar outros deste encargo, e de que maneiras e modos tal projeto possa ser feito mais efetivo; nós humildemente pedimos permissão para mostrar perante vossas Excelências um esquema de tais métodos os quais parecem a nosso ver os mais apropriados para a obtenção de tais fins.

A multiplicação dos pobres, e o aumento das taxas para a sua manutenção, têm uma observação e reclamação tão generalizadas, que não podem ser duvidadas; nem foram senão desde a última guerra quando este mal chegou a nós; têm sido um fardo crescente no reino nestes tantos anos; e os dois últimos reinos sentiram o seu aumento, bem como o atual.

Se as causas deste mal forem investigadas, nós humildemente entendemos que ele não será considerado ter procedido nem da escassez de provisões nem da falta de emprego para os pobres, já que a bondade de Deus tem abençoado esta época com fartura, não menos que a anterior, e uma longa paz durante estes reinos nos deu um comércio abundante como nunca. O crescimento dos pobres deve então ter alguma outra causa; e só pode ser o relaxamento da disciplina, e a corrupção dos hábitos; a virtude e a diligência sendo companheiros constantes de um lado, assim como o vício e a ociosidade estão de outro.

O primeiro passo, portanto, em direção da colocação dos pobres no trabalho, nós humildemente entendemos, deve ser a restrição de sua libertinagem, mediante a aplicação estrita das leis providas contra ela; mais particularmente pela supressão das supérfluas lojas de conhaque e dos desnecessários bares, especialmente em paróquias rurais não localizados na beira de grandes estradas.

Se todas as mãos hábeis fossem levadas ao trabalho, a maior parte do fardo que os trabalhadores carregam para a manutenção dos pobres imediatamente cessaria: pois, através de um cálculo muito moderado, pode ser concluído que mais da metade daqueles que recebem assistência das paróquias são capazes de obter seu sustento; e todos aqueles que recebem tal assistência das paróquias, nós entendemos, devem ser divididos nos seguintes tipos:

Primeiro, aqueles que não conseguem fazer coisa alguma a fim do seu sustento.

Segundamente, aqueles que, apesar de não conseguirem se manter totalmente, são capazes de fazer alguma coisa para isto. 
Terceiramente, aqueles que são capazes de se manterem através do seu próprio trabalho.

E, estes últimos, podem ser novamente subdivididos em dois tipos: a saber, aqueles que tenham família com crianças numerosas, a qual eles não podem ou fingem que não conseguem sustentar com seu próprio trabalho; ou aqueles que fingem não conseguir trabalho, e então vivem apenas mendigando ou coisa pior.

Para a supressão deste último tipo de mendigos parasitas, que vivem desnecessariamente do trabalho de outras pessoas, já existem leis boas e íntegras, suficientes para o propósito se devidamente executadas. Nós, portanto, humildemente propomos que a execução das mesmas possa ser retomada, no presente, através de um decreto, até que outras reparações sejam providenciadas. Bem como, que a ordenação seja feita todos os anos, para a escolha dos guardas da igreja e supervisores dos pobres, que os estatutos da 39틀. cap. 4 e Eliz. cap 2 sejam lidos e considerados parágrafo a parágrafo, e que a observação deles, em todas as suas partes, sejam forçadas naqueles que devem ser inspetores. Pois temos razão para pensar que a maior parte dos inspetores dos pobres, em todo lugar, são totalmente ignorantes; e nunca acham que seja a maior parte, ou sequer qualquer parte, do seu dever, fazer as pessoas trabalharem.

Mas, para a mais efetiva repressão dos vagabundos ociosos, nós ademais humildemente propomos que uma nova lei possa ser obtida, pela qual seja promulgado:

Que todos os homens sãos de corpo e mente, acima de quatorze e abaixo de cinquenta anos de idade, mendigando em condados marinhos, fora de sua paróquia sem um passe, devam ser apreendidos, seja por um oficial da paróquia onde eles mendigam (tais oficiais, por causa dos seus ofícios, devem ser autorizados, e sob penalidade requeridos a fazê-lo) ou pelos próprios habitantes da casa onde eles mendigam; e por eles ou qualquer deles, trazidos perante o próximo juiz de paz ou guardião dos pobres (a ser escolhido conforme futuramente mencionado), que neste caso deve ter o poder de juiz de paz; e por tal juiz de paz ou guardião dos pobres (depois da devida e usual correção no caso), ser através de um passe enviado, não para a casa de correção (já que tais casas na maioria dos condados são atualmente ditas serem um lugar de comodidade e de nomeação dos mestres dali, do que de correção e melhoria daqueles que são enviados para ali); nem para os seus locais de habitação (já que tais vagabundos ociosos normalmente citam algum lugar remoto, para o qual o país sofre um enorme custo; e eles normalmente escapam dos oficiais negligentes antes de chegar lá, e então estão em liberdade para uma nova caminhada). Mas, se for em um condado marítimo, como supracitado, que sejam enviados para a próxima cidade portuária, para serem mantidos no trabalho forçado até que algum dos navios da vossa majestade vindos ali ou perto dali deem uma oportunidade de colocá-los a bordo, onde devem servir três anos sob rígida disciplina, com salário de soldado (dinheiro de subsistência sendo deduzido seu consumo a bordo), e serem punidos como desertores se forem para a costa sem permissão; ou, quando enviados à costa, se forem além ou permanecerem mais tempo, do que têm permissão.

Que todos os homens mendigando em condados marítimos sem passe, que sejam mutilados, ou se tiverem mais de cinquenta anos de idade; e todos de qualquer idade mendigando sem passe em condados continentais que não façam fronteira com 0 mar, devam ser enviados para a próxima casa de correção, para lá serem mantidos no 
trabalho forçado por três anos.

E com a finalidade que o verdadeiro uso das casas de correção não seja pervertido, já que ultimamente tem sido na maior parte delas, que o mestre de cada casa seja obrigado a conceder para cada um submetido à sua responsabilidade $4 \mathrm{~d}$ por dia para o seu sustento em Londres. Mas em condados mais remotos, onde os salários e provisões são mais baixos, o valor deve ser estabelecido pelo grande júri e juiz na corte: para o qual o designado mestre não deve ter outra consideração ou salário além do que o trabalho deles produzir; e que, portanto, deve ter o poder de empregar de acordo com a sua decisão, levando em consideração a sua idade e força.

Que o juiz de paz deva, a cada trimestre, fazer uma breve investigação no estado e gerenciamento das casas de correção dentro de sua paróquia; e fazer um rígido relato da postura de todos que lá estão; e se eles acharem que alguém for resistente, e não recuperado pela disciplina do lugar, que ordenem uma estada mais longa ali, e disciplina mais severa; que assim ninguém seja mandado embora até que tenha dado prova evidente de correção, a finalidade para a qual ele foi enviado para ali.

Que seja quem for que falsifique um passe deva perder suas orelhas pela falsificação na primeira vez que for considerado culpado do mesmo; e,, na segunda vez, que seja transportado para as lavouras, como no caso de crimes.

Que qualquer mulher, acima de quatorze anos de idade, que seja encontrada mendigando fora de sua paróquia sem um passe (se ela for habitante de uma paróquia até 5 milhas de distância do qual foi encontrada mendigando) ela deve ser conduzida para sua paróquia pelo policial, pelo líder do tithing, pelo inspetor dos pobres, pela guarda da igreja, ou por outro oficial juramentado da paróquia onde ela foi encontrada mendigando; o qual pelo seu lugar e cargo deve ser requerido a fazê-lo, e entregá-la ao inspetor dos pobres da paróquia a qual ela pertence, de quem ele deve receber $12 \mathrm{~d}$ pelo seu incômodo; cujos 12d, se ela receber assistência pública, devem ser deduzidos do seu salário paroquial; ou, se ela não for assistida pela paróquia, deve ser arrecadado dos bens dela, ou de seus pais ou de seu mestre.

Que quando qualquer mulher, acima e quatorze anos, dentro da mesma distância, cometer o mesmo erro pela segunda vez; e quando a mesma ou qualquer outra mulher for encontrada mendigando sem um passe legal, pela primeira vez, a uma distância maior que cinco milhas do lugar de sua residência, deve ser legitimado para qualquer juiz de paz ou guardião dos pobres, após queixa, mandá-la para a casa de correção, e lá ser empregada em trabalho forçado por três meses, e por quanto tempo for até o próximo trimestre, após a determinação dos ditos três meses; e que então, após devida correção, ela tenha um passe feito para ela pelas sessões para levá-la para casa, ao lugar de sua moradia.

Que se algum menino ou menina, abaixo de quatorze anos de idade, for encontrado mendigando fora da paróquia onde eles habitam (se dentro de cinco milhas de distância de tal paróquia) eles devem ser enviados para a próxima working-school, onde deve ser exaustivamente chicoteado, e mantido no trabalho até o anoitecer, para que possa ser mandado embora com tempo suficiente para que consiga chegar ao seu lugar de moradia ainda naquela noite. Ou, se eles morarem mais longe do que cinco milhas do lugar onde forem encontrados mendigando, que sejam enviados para a próxima casa de correção, para lá permanecerem trabalhando por seis semanas, e quanto tempo mais até 
a próxima sessão após o final das ditas seis semanas.

Com estes vagabundos ociosos sendo assim suprimidos, não haverá (nós pressupomos), na maioria das paróquias, homens que tenham a falsa aparência de que querem trabalho. Porém, a fim de remover esta falsa aparência, quando ela acontecer, nós humildemente propomos que seja ainda promulgado:

Que o guardião dos pobres da paróquia onde tal falsa aparência for feita, no próximo domingo após a queixa ser feita a ele, comunique à paróquia que tal pessoa alega querer trabalho, e deve então perguntar se alguém está disposto a empregá-lo, a um valor mais baixo do que é normalmente pago, cujo valor estará no poder de tal guardião definir; pois não é pressuposto que alguém seja recusado a ser empregado por seus vizinhos, enquanto outros se lançam ao trabalho, a não ser por algum defeito em sua habilidade ou honestidade, para o qual é razoável que ele deva sofrer; e aquele que não pode se pôr a trabalhar por $12 \mathrm{~d}$ por dia, deve se contentar com $9 \mathrm{~d}$ ou $10 \mathrm{~d}$, ao invés de viver ociosamente. Mas, se ninguém na paróquia voluntariamente aceitar tal pessoa pelo valor proposto pelo guardião dos pobres, que então fique no poder do dito guardião, com o resto da paróquia, fazer uma lista de dias, de acordo com a proporção das taxas para os pobres de todos na paróquia; e que, de acordo com tal lista, cada habitante da mesma paróquia deve ser obrigado na sua vez de dar à tais homens pobres desempregados trabalho, a tais valores baixos como o dito guardião dos pobres deve apontar: e se alguém se recusar a dar trabalho ao pobre na sua vez como assim dirigido, que tal pessoa esteja sujeito a pagar seus salários estipulados, empregando-os ou não.

Que se qualquer homem pobre, desempregado de outra forma, se recusar a trabalhar de acordo com tal ordem (se estiver em um condado marítimo), ele deve ser mandado ao próximo porto, e lá colocado a bordo de algum dos navios da vossa Majestade, para lá servir por três anos, como proposto antes; e que o pagamento que ele acumular pelo seu serviço lá, superior a sua comida e roupas, seja pago ao inspetor dos pobres da paróquia à qual ele pertence, para a manutenção da sua esposa e filhos, se ele os tiver, ou então para a assistência de outro pobre da mesma paróquia: mas (se não for em um condado marítimo) que todo homem pobre, que assim se recuse a trabalhar, deva ser enviado à casa de correção.

Estes métodos, nós humildemente propomos como apropriados a serem promulgados, a fim de empregar os pobres que são capazes, mas não trabalham; os quais, pela execução pontual de tal lei, nós humildemente entendemos podem ser rapidamente reduzidos à um número muito pequeno, ou quase extintos. Mas a maior parte dos pobres mantidos pelas taxas da paróquia não são absolutamente incapazes, nem totalmente relutantes, a fazer alguma coisa a fim de obter seu sustento; mas mesmo estes, seja por querer um trabalho compatível provido a eles, ou sua inabilidade em trabalhar no que pode ser uma vantagem à população, fazem pouco que resulte em alguma fatura; mas vivem ociosamente com o salário da paróquia, ou mendigando, se não coisa pior. O seu trabalho, portanto, desde que eles sejam capazes de trabalhar, deve ser guardado para a população; e que o quanto seus rendimentos forem abaixo da sua completa manutenção, deva ser suprido do trabalho de outros, ou seja, do salário da paróquia.

Estes são de dois tipos: 
1. Pessoas adultas; que, decadentes da sua força integral, ainda podem fazer algo pelo seu sustento, mas sob o pretexto de que eles não conseguem emprego, eles geralmente não fazem nada. Neste mesmo caso estão a maioria das esposas dos trabalhadores, quando eles têm dois ou mais filhos: o cuidado das crianças não lhes dá liberdade de sair do condado e procurar emprego; e então, não encontrando emprego em casa, nos intervalos quebrados do seu tempo elas não ganham nada. Mas a ajuda da paróquia é solícita em vir ao seu auxílio; e seu trabalho é totalmente perdido, o que é uma grande perda para a população.

Todos devem ter comida, bebida, roupa e aquecimento; tanto sai do estoque do reino, eles trabalhando ou não. Supondo, então, que existam 100.000 pobres na Inglaterra que vivam da paróquia; ou seja, que são sustentados pelo trabalho de outras pessoas (pois assim são todos que vivem de caridade sem trabalhar); se a assistência fosse tirada, que cada um daqueles, por algum trabalho na fabricação de lã ou outro produto, ganharia ao menos 1d por dia (o que um ou outro vai conseguir fazer, e mais) isso renderia à Inglaterra $£ 130.000$ por ano, o que em oito anos faria a Inglaterra mais de um milhão de libras mais rica.

Isto, devidamente considerado, nos mostra o que é a verdadeira e apropriada assistência aos pobres: ela consiste em encontrar trabalho para eles, e cuidar para que eles não vivam como parasitas do trabalho dos outros. E, para este fim, nós entendemos que as leis feitas para a assistência aos pobres foram intencionadas: porém por uma ignorância da sua intenção, ou uma negligência da sua devida execução, elas são usadas apenas para a manutenção das pessoas em ócio, sem examinar as suas vidas, habilidades, ou diligência daqueles que procuram a assistência.

A fim de suprimir estes mendigos ociosos, as corporações da Inglaterra têm sacristãos autorizados e pagos para prevenir a quebra da lei neste item: mas, apesar disso, as ruas por todo lugar estão cheias de mendigos, para o aumento do ócio, pobreza e vilania, e para a vergonha da Cristandade. E se for perguntado, em qualquer cidade da Inglaterra, quantos destes visíveis transgressores foram pegos e trazidos à julgamento por aqueles oficiais neste último ano, nós temos motivo para pensar que o número seria bem pequeno; por isso uma multidão de mendigos nas ruas é manifestamente grande.

Mas a solução para este transtorno é tão bem provido pelas leis atualmente em vigor, que nós podemos imputar a continuidade e o aumento do mesmo a nada além do que a geral negligência de sua execução.

2. Além das pessoas adultas mencionadas acima, os filhos das pessoas trabalhadoras são um corriqueiro fardo para a paróquia, e, normalmente, são mantidos na ociosidade; e o que produziriam também é geralmente perdido pela população até eles atingirem doze ou quatorze anos de idade.

A solução mais efetiva para isto que nós somos capazes de conceber e que, portanto, nós humildemente propomos, é, que na lei acima mencionada a ser decretada seja também determinado que working-schools sejam estabelecidas em todas paróquias, para as quais as crianças que necessitem de assistência da paróquia, acima de três e abaixo de quatorze anos de idade, enquanto morarem em casa com seus pais, e não forem de outra forma empregados para a sua subsistência pelo salário dos inspetores dos pobres, devem ser obrigados à frequentar. 
Deste modo a mãe será aliviada de grande parte da sua dificuldade em cuidar e prover por eles em casa, e então estará em maior liberdade para trabalhar; as crianças ficarão em uma organização melhor, estarão mais bem providas, e desde a sua infância estarão habituados a trabalhar, o que não é de pouca consequência para torná-los sóbrios e diligentes durante toda a sua vida; e a paróquia será aliviada do seu fardo, ou ao menos do mau uso no presente gerenciamento do mesmo: pois há um grande número de crianças dando o direito a um salário da paróquia, este salário é dado uma vez por semana, ou uma vez ao mês para o pai em dinheiro, o qual ele não raramente gasta em si mesmo no bar, enquanto seus filhos (para cuja causa ele o tinha) são deixadas a sofrer, ou perecer sob o desejo do essencial, a menos que a caridade dos vizinhos os auxiliem.

Nós humildemente entendemos que o homem e sua esposa, em saúde, podem ser capazes pelo seu trabalho quotidiano de manterem a si mesmo e dois filhos. Mais que dois filhos de uma vez, abaixo de três anos de idade, raramente acontecerá em uma família: se, portanto, todos os filhos acima de três anos de idade forem retirados de suas mãos, aqueles que nunca tiveram tanto, enquanto eles permanecem saudáveis, não necessitarão de salário para eles.

Nós não supomos que crianças de três anos de idade serão capazes em tal idade de obter o seu sustento em working-schools; mas nós estamos certos que o que é necessário para sua assistência terá mais efetivamente este uso, se for distribuído a eles na forma de pão naquela escola, do que se dado aos seus pais em dinheiro. $O$ que eles têm em casa, dos seus pais, é raramente mais do que pão e água, e muito disso é também muito escasso: se, portanto, se tomar cuidado que eles tenham cada um deles a barriga cheia de pão diariamente na escola, eles não estarão em perigo de passar fome; mas, pelo contrário, eles estarão mais saudáveis e fortes do que aqueles que forem criados de outra maneira. Não só irá essa prática custar aos inspetores trabalho algum; pois um padeiro pode ser designado a fornecer e trazer para a escola-casa, todos os dias, o subsídio de pão necessário para todas as crianças que lá estão. $E$ a isso pode também ser adicionado, sem nenhum incômodo, no clima frio, se for considerado necessário, um pouco de sopa de aveia e água quente; pois o mesmo fogo que esquenta a sala pode ser usado para ferver uma panela do mesmo.

Deste método, as crianças não vão apenas colher as vantagens acima mencionadas com muito menos custo à paróquia do que é agora feito por elas, mas elas também estarão assim mais obrigadas a virem à escola e aplicarem-se ao trabalho, porque de outra forma eles não terão comida e também o benefício para ambos, eles e a paróquia, irá aumentar diariamente: pois com os ganhos do seu trabalho na escola todos os dias aumentando, é razoável de se concluir que, ao computar todos os rendimentos de uma criança de três à quatorze anos de idade, a nutrição e ensino de tal criança durante todo aquele tempo não terá custo algum à paróquia. Apesar de não haver criança alguma atualmente que seja mantida pela paróquia desde o nascimento, ainda assim antes da idade de quatorze, ela custa à paróquia cinquenta ou sessenta libras.

Uma outra vantagem também em trazer crianças pobres para uma workingschools é que desta forma elas podem ser obrigadas a ir constantemente à igreja todo domingo juntamente dos seus mestres escolares ou damas, onde elas podem ser trazidas à algum sentido religioso; ao passo que atualmente, no seu ocioso e livre modo de criação elas são completas estranhas tanto à religião e à moralidade como à diligência. 
A fim de, portanto, uma mais efetiva continuidade deste trabalho para benefício deste reino, nós adicionalmente humildemente propomos, que estas escolas sejam geralmente para tecelagem e tricô, ou outra parte da produção de lã; a não ser em países onde o lugar fornecer outros materiais mais apropriados para o emprego de tais crianças pobres; nestes lugares a escolha destes materiais para o emprego deve ficar a cargo da prudência e direção dos guardiões dos pobres daquela centena; e que os professores nestas escolas sejam pagos das taxas dos pobres, como poderá ser acordado.

Isto, embora ao inicialmente implantar, possa custar um pouco à paróquia, ainda assim nós humildemente entendemos que (os ganhos das crianças reduzido do custo da sua manutenção, e com tanto trabalho sendo requerido deles quanto cada um pode razoavelmente realizar) irá rapidamente pagar os próprios custos, com um superávit.

Que onde o número de crianças pobres de qualquer paróquia seja maior que para todos serem empregados em uma escola, eles sejam lá divididos em dois; e os meninos e meninas, se considerado conveniente, ensinados e mantidos a trabalhar separadamente.

Que os artesãos em cada centena estejam sujeitos a tomar cada um de seus aprendizes dentre os meninos em alguma das escolas na dita centena sem nenhum dinheiro, cujos meninos eles podem tomar a qualquer idade que os agrade, para estarem comprometidos a eles até a idade de vinte e três anos, para que o período possa mais do que reparar as somas usuais que são dadas aos artesãos com tais aprendizes.

Que aqueles também na centena que mantiverem em seu poder terras próprias no valor de £25 por ano ou mais, ou que alugarem £50 por ano ou mais, possam escolher nestas escolas da dita centena qual menino de cada uma os agrada para ser seu aprendiz em pecuária, nas mesmas condições.

Que quaisquer meninos que não forem desta forma aprendizes comprometidos antes de terem quatorze anos completos, devem, nos encontros de páscoa dos guardiões de cada centena todo ano, estar sujeitos a tais cavalheiros, guarda real, ou fazendeiros, dentro da dita centena, o que tiver o maior número de acres de terra em seu poder; que deve ser obrigado a tomá-los como aprendizes até a idade de vinte e três, ou empregá-los a seu próprio custo a algum artesão; provido sempre que nenhum cavalheiro, guarda real ou fazendeiro estará sujeito a ter dois aprendizes por vez.

Que as pessoas adultas também (para remover o seu fingimento de querer trabalhar) podem vir às referidas working-schools para aprender, onde trabalho deve ser apropriadamente provido a eles.

Que os materiais a serem empregados nestas escolas, e entre outros as pessoas pobres da paróquia, sejam providos por um estoque comunitário em cada centena, para ser criado a partir de certa porção da taxa dos pobres de cada paróquia como requisito; e tal estoque, nós humildemente entendemos, necessita ser criado apenas uma vez; pois, se corretamente gerenciado, irá aumentar.

Que alguma pessoa, experiente e habilidosa na produção em particular que deve ser julgada mais apropriada para colocar os pobres de cada centena no trabalho, seja apontada armazenista para aquela centena, que deve assim comprar a lã ou outro material necessário; que este armazenista seja escolhido pelos guardiões dos pobres de cada centena, e estar sob a sua direção, e ter um salário conforme eles considerem que 
deva ser pago, pro rata com a libra, das taxas dos pobres de cada paróquia; e acima de tal salário, que ele também receba dois xelins ingleses de libra anualmente para cada vinte xelins ingleses que sejam diminuídos da taxa dos pobres de qualquer paróquia, a partir do primeiro ano da sua gerência.

A este armazenista um dos inspetores dos pobres de cada paróquia deve reparar tão frequente quanto houver ocasiões, para buscar para ele os materiais para o emprego dos pobres de cada paróquia, cujos materiais o referido inspetor deve distribuir aos professores das crianças de cada escola; e também aos outros pobres que necessitam de assistência da referida paróquia, a ser forjado por eles em casa na quantidade que ele ou o guardião da paróquia julgue razoável para cada um deles, respectivamente, despachar em uma semana; concedendo a cada pessoa pobre, pelo seu trabalho, o que ele e o armazenista concordem valer. Mas se o referido inspetor e o armazenista não concordarem no valor de qualquer trabalho, que então qualquer três ou mais dos guardiões daquela centena (sendo o guardião da mesma paróquia onde surja a contestação, deve ser sempre uma) irão determiná-lo.

Que a venda do material assim manufaturado seja feita pelo armazenista na presença de um ou mais dos guardiões de cada centena, e não de outra forma; e que uma conta exata seja mantida pelo referido armazenista de tudo que ele comprar e vender; como também de várias quantidades de materiais não forjados que ele entregar aos respectivos inspetores, e do retorno manufaturado que ele receber de volta deles.

Que se qualquer pessoa a quem lá ou qualquer outro material forem entregues para serem forjados se estraguem ou sejam roubados, se for alguém que receba caridade da paróquia, os inspetores dos pobres daquela paróquia devem pagar ao armazenista o seu custo, e deduzir aquela soma do salário da paróquia para a pessoa que estragou ou roubou qualquer dos referidos materiais; ou se for algum que não receba salário da paróquia, então o referido inspetor deve exigi-lo em dinheiro da pessoa que estragou ou roubou-os; e se a pessoa ofensivamente se recusar a pagá-lo, o guardião dos pobres daquela paróquia, sob juramento feito a ele por qualquer dos ditos inspetores que ele entregue tais materiais a tal pessoa, e que ele pague a eles tal soma ao armazenista (cujo juramento todo guardião deve ter o poder de administrar), deve conceder ao referido inspetor um mandado para tomar como garantia os bens da pessoa ofensora, e vender os bens tomados, gerando uma sobra.

Que o guardião dos pobres de cada paróquia, a ser escolhido por aqueles que pagam à assistência dos pobres da referida paróquia, deve ser escolhido, pela primeira vez, dentro de três meses após a aprovação do ato agora proposto. Que os guardiões assim escolhidos pelas respectivas paróquias de cada centena devam ter inspecionado todas as coisas relacionadas ao emprego e assistência dos pobres da referida centena. Que um terço do número total de guardiões de cada centena assim escolhidos deva sair todos os anos; no primeiro ano em grupo, do número total; no segundo ano por grupo dos remanescentes dois terços, todos devem continuar durante três anos sucessivamente, e não mais tempo. E que, para o suprimento de qualquer vacância, pois isto deve acontecer, um novo guardião deva ser escolhido como dito anteriormente em qualquer das respectivas paróquias, ao mesmo tempo em que os inspetores dos pobres são escolhidos lá, ou a qualquer tempo dentro de um mês após tal vacância.

Que os guardiões dos pobres de cada respectiva centena devam se encontrar 
todos os anos na semana de Páscoa, no local onde as lojas daquela centena são mantidas, para tomar conta do estoque; e o quão frequentemente, também, em outros momentos conforme forem necessários, para inspecionar o gerenciamento do mesmo, e dar direções nisso, e em todas as outras coisas relacionadas aos pobres daquela centena.

Que a nenhuma pessoa de qualquer paróquia seja concedido um salário da paróquia sem o consentimento conjunto do guardião da referida paróquia e da sacristia.

Que os referidos guardiões também, cada um deles, dentro da centena onde for o guardião, tenha o poder de juiz de paz sobre os vagabundos e mendigos, para emiti-los passes, manda-los a cidades portuárias, ou casas de correção, como anteriormente proposto.

Estas supramencionadas regras e métodos sendo o que nós humildemente entendemos mais apropriados de serem colocados em pratica para o emprego e assistência dos pobres em geral ao longo do país, nós agora adicionalmente propomos, para a melhor e mais fácil obtenção do mesmo, e em cidades e municípios corporativos, que seja promulgado:

Que em todas as cidades e municípios, a taxa dos pobres não será imposta por paróquias distintas, mas por uma taxa igual em toda a corporação.

Que em cada corporação existam doze guardiões dos pobres, escolhidos pela referida corporação; onde quatro devem sair em grupo no final do primeiro ano; outros quatro do remanescente número devem sair também em grupo no ano seguinte; e os quatro remanescentes no terceiro ano; e novos quatro escolhidos a cada ano no lugar daqueles que saírem, para manter o número de doze completo; e que ninguém continue acima de três anos consecutivos.

Que estes guardiões tenham o poder de criar e demandar working-schools, conforme acharem conveniente, dentro de cada corporação respectivamente; em tais escolas as crianças de todos que são assistidos por tal corporação, dos três aos quatorze anos de idade, devem estar obrigadas a vir, enquanto eles continuarem desempregados em outro serviço estabelecido a ser aprovado pelo inspetor dos pobres daquela paróquia a qual eles pertencem.

Que estes guardiões também tenham o poder exclusivo de requerer e dispor do dinheiro arrecadado em cada corporação para o uso dos pobres, seja para prover o material para colocá-los a trabalhar, ou para ao alívio daqueles que eles julguem não capazes de obter seu próprio sustento; e que eles sejam os juízes exclusivos de quem seja ou não seja qualificado a receber assistência pública, e em que proporção.

Que os referidos guardiões também tenham o poder de enviar qualquer pessoa mendigando sem um passe legal para a próxima cidade portuária, ou casa de correção, como anteriormente proposto.

Que eles tenham igualmente o poder de apontar um tesoureiro para receber todo o dinheiro obtido da assistência aos pobres; cujo tesoureiro deva emitir todo dinheiro somente sob seu comando, e deve uma vez ao ano passar por eles as suas contas: e que eles também apontem um ou mais armazenistas, conforme eles acharem necessário, com recompensas ou salários que eles estimarem apropriados; e estes armazenistas devem de modo semelhante responder à eles. Provido sempre que o prefeito ou oficial de justiça, 
ou outro comandante de cada corporação, tenha uma notificação entregue a ele de que ele deva estar presente (o que nós humildemente propomos seja ordenado a todos os oficiais respectivamente) na passagem das contas do tesoureiro e do armazenista dos pobres dentro da respectiva corporação.

Que os professores em cada escola, ou outra pessoa lá nomeada, deva pegar dos respectivos armazenistas o material com o qual eles são indicados a trabalhar dentro da escola, e em tal quantidade que forem solicitados; e tais materiais devem ser manufaturados adequadamente, e então devolvidos ao armazenista, e por ele ser, ou dado para ser novamente manufaturado, ou então descartado da maneira mais vantajosa, como os guardiões comandarem.

Que os inspetores dos pobres devam do mesmo modo pegar com o armazenista, e distribuir para aqueles sob assistência pública, tais materiais, e em tais proporções, conforme for comandado a eles para uma semana de trabalho, e não pagar nenhum pobre assim empregado o salário apontado a eles, até que eles devolvam suas respectivas tarefas bem cumpridas.

Que os inspetores dos pobres de cada paróquia devam ser escolhidos conforme são agora, e tenham o mesmo poder de coletar as taxas dos pobres das suas respectivas paróquias como agora: mas que eles distribuam o dinheiro assim coletado para a assistência e manutenção dos pobres, de acordo com as ordens e direções que eles recebam dos guardiões; e que as contas dos inspetores dos pobres de cada paróquia, ao final do seu ano, deva ser demonstrada ante as pessoas que a paróquia aponte para inspecioná-las, que eles possam fazer observações nas referidas contas, ou exceções contra elas, conforme eles sejam responsáveis. E que então as referidas contas, com aquelas observações e exceções, sejam examinadas pelo tesoureiro e dois dos guardiões (onde um será nomeado pelos guardiões, e outro pela paróquia); e que as referidas contas passem pela concessão dos três.

Que os referidos guardiões devam ter poder de apontar um ou mais sacristães de mendigos; cujos sacristães devam ser autorizados e requeridos a confiscar qualquer estranho mendigando nas ruas, ou qualquer um da referida corporação mendigando, ou sem um distintivo apontado a ser usado, ou em horas não permitidas pelos referidos guardiões a mendigar, e trazer todas as pessoas ante qualquer um dos guardiões: e que, se qualquer dos sacristães negligenciar sua referida obrigação, e que estranhos ou outros mendigos não tendo o distintivo apontado ou em horas não permitidas, forem encontrados frequentando as ruas, o referido guardião (após reclamação então feita a eles) devem ter o poder e serem requeridos a punir o sacristão ofensor (pela primeira falha) de acordo com sua própria discrição; mas, após uma segunda reclamação provada ante eles, que eles enviem o referido sacristão para a casa de correção, ou (se for em um condado marítimo, e o sacristão ofensor for um homem saudável, e abaixo de cinquenta anos de idade) para a próxima cidade portuária, a fim de colocá-lo a bordo de algum dos navios da vossa majestade, para lá servir por três anos, como proposto anteriormente.

Que aqueles que não são capazes de trabalhar de jeito nenhum, em corporações onde não haja hospitais para recebê-los, sejam alojados três ou quatro ou mais em um quarto, e ainda mais em uma casa, onde um fogo poderá servir, e um atendente poderá manter muitos deles, com menor custo que quando eles moram sozinhos e dispersos.

E já que o comportamento e vontade dos pobres são mais bem conhecidos entre 
os seus vizinhos, e que eles podem ter a liberdade de declarar suas vontades, e receber pedaços de pão e de carne, ou outra caridade, de pessoas bem-intencionadas; que seja então permitido àqueles cujos nomes forem inseridos no livro dos pobres, e que vistam os requeridos distintivos, pedir e receber caridade, nas suas respectivas paróquias, em certos horários do dia, a serem marcados pelos guardiões. Mas se algum deles for encontrado mendigando em algum outro horário fora daqueles permitidos, ou fora das suas respectivas paróquias, apesar de dentro da mesma corporação, devam ser imediatamente enviados (se eles tiverem menos de quatorze anos de idade) para a working-school, para serem chicoteados; e (se eles tiverem mais de quatorze anos) para a casa de correção, para permanecerem lá por seis semanas, e quanto tempo faltar até o próximo trimestre depois que as referidas seis semanas tiverem terminado.

Que se alguma pessoa morrer por falta de devido auxílio em qualquer paróquia onde ela deva ser auxiliada, a referida paróquia seja multada de acordo com as circunstâncias do fato e da gravidade do crime.

Que cada mestre dos navios do rei esteja sujeito a receber, sem dinheiro, uma vez ao ano (se oferecido a ele pelo prefeito ou outro oficial de qualquer lugar dentro dos limites do porto onde seu navio esteja) um menino, saudável, acima de treze anos de idade, que deverá ser seu aprendiz por nove anos. 